\title{
On the Phonetics and Phonology of Focus Marking in Boro
}

\author{
Shakuntala Mahanta, Kalyan Das and Amalesh Gope \\ Indian Institute of Technology Guwahati, India
}

\section{Introduction}

Tone languages do not generally have complex intonation systems and thus European languages with lexical tone contrast, like Swedish and Norwegian, have simpler intonation systems than English, a language without lexical tone (Gussenhoven and Vliet 1999). However, focus marking strategies employed in tone languages provide crucial information as to the extent intonational modification allowed in these languages. It has been widely discussed in the literature of tone that the semantic-pragmatic category of focus can not only be encoded by means of morphological and syntactic means, but also by the use of intonation. Gussenhoven (2004) notes that tone languages do make use of f0 modifications at the level of intonation. Evidence comes from a language like Mandarin Chinese where a non-final focus substantially expands the pitch range, particularly the upper end of the words directly under focus, and it suppresses the pitch range of post focus words. (Xu 1999). In Kammu, focus is expressed at the level of prosody by increasing the pitch range of the boundary tone of the phrase under focus (Karlsson, Svantesson and House 2012). A language like Akan with two tonal oppositions (Low and High), expresses contrastive and narrow focus with tonal lowering for lexical $\mathrm{H}$ and L tones (Kügler and Genzel 2012). Other tone languages like the Dutch dialect of Venlo (Gussenhoven and Vliet 1999) and Chichewa (Myers 1996) also show some amount of $\mathrm{f0}$ modification to express intonation. This paper discusses how focus is expressed in Boro by using prosodic means.

Boro belongs to the Tibeto-Burman group of languages, and forms a branch along with Garo, Dimasa, Tiwa, Rabha and Kok-Borok. Boro is spoken by 1,350,478 people (male 655,032 and female 641,130$)^{1}$ in the Indian state of Assam, mainly in Darrang, Nagoan, Kamrup, Goalpara, Sibsagar, Kokrajhar, Dhubri, Chirang, Baksa, Udalguri districts and also in the states of West-Bengal, Manipur, Meghalaya, and in Nepal where it is known as Meche. ${ }^{2}$ Boro lexically distinguishes L and $\mathrm{H}$ tones. Monosyllabic words in isolation have two contrasting tone patterns which are phonetically realized as rising and falling. These can be analyzed as underlying H and L respectively (Burling 1959, Sarmah 2004). Their surface phonetic manifestation is that of rising tone in the case of High lexical tone and the Low lexical tone is not only pronounced with falling contour but also with a low level tone at other times. In Boro, distinctive $\mathrm{H}$ and $\mathrm{L}$ tones appear on the rightmost syllable. It has been proposed by Sarmah (2004) that every non-derived lexical entry in Boro is assigned only one tonal specification. Sarmah proposes a rule of tone association to the rightmost syllable and a rule of default mid tone insertion, to apply in that order. Additionally, in Boro words, it is not possible to have tones in both syllables. When there is more than one syllable (Boro roots are mostly monosyllabic or disyllabic) the Tone Bearing Unit (TBU) is always the second syllable. The examples in (1) show the distributions of underlying tones in Boro monosyllables, derived and underived disyllables.

\section{(1) Distributions of Tones in Boro}

$\begin{array}{lllll}\text { Underlying } & \text { Surface tone } & \text { Monosyllables } & \text { Derived Disyllables } & \text { Underived Disyllables } \\ \text { High } & \text { Rising } & \text { bái 'break' } & \text { baigún 'will break' } & \text { hat } \\ \text { Low } & \text { Falling } & \text { bài 'buy' } & \text { baigùn 'will buy' } & \text { hathài }\end{array}$

Suffixation shows right aligned tonal specification in disyllables as can be found in (1). We will see how these rules work in the phrasal domain in section 5. It will be shown how the requirement of disyllabicity controls the process of underlying tonal specifications surfacing on the rightmost boundary in

\footnotetext{
${ }^{1}$ Source: http://www.censusindia.gov.in , retrieved on May 10, 2013

${ }^{2}$ Source: http://www.ethnologue.com , retrieved on May 10, 2013

(C) 2016Shakuntala Mahanta, Kalyan Das, and Amalesh Gope

Proceedings of AMP 2015

Completed March 28, 2016
} 
derived words. Based on evidence it will also be proposed that at the phrasal level, the pre-specified right alignment of tonal specification has to yield to the pitch accent of the MF marker.

The intonation pattern of Boro has not been the subject of any research barring a few minor comments on the overall contour patterns by Bhattacharya (1977) and Joseph and Burling (2006). Bhattacharya (1977) observes that the tonal contour of Boro syllables before pause or terminal juncture are of different types and this is related to the kind of pragmatic meaning the stretch of utterance expresses. Joseph and Burling (2006) notice the existence of other tonal patterns in Boro in addition to lexical pitch and suggest that these variations may result from interference from question intonation and emphasis, which can significantly modify the underlying tone. Das and Mahanta (2016c) present acoustic and statistical evidence to show that in Boro intonation, the lexical tones of words which are non-final are always preserved. This study also shows how the final occurrences of the lexical tones in the language are modified by both monotonal and bitonal boundary tones. On the other hand, contrastive and corrective focus are expressed in the language by lowering the pitch range of the Intonational Phases (IP) (Das and Mahanta 2016a). Our experiments show that at a postlexical stage, downstep processes lead to additional tonal levels, like the downstepped high. Our experiment showed that the MF marker led to differences in the tonal realization of $\mathrm{H}$ and $\mathrm{L}$ tones. While $\mathrm{H}$ tones were realized at a higher $\mathrm{fo}$ because of the MF marker, $\mathrm{L}$ tones did not lead to any changes unless they were disyllabic. The same result held for the nominative case marker [-a].

The intonational structure of underlying tones in Boro is the following. Underlying $\mathrm{H}$ is always realized as $\mathrm{H}$ in all other positions except the final position. Underlying $\mathrm{H}$ is always realized as $\mathrm{L} \%$ in the final part of the sentence owing to sentential boundary tones. Underlying $\mathrm{L}$ is always realized as $\mathrm{L}$. This predictable picture may be disturbed by the presence of the MF markers [sú/nú]. [sú/núu] exhibit duality in the way it influences $\mathrm{H}$ and $\mathrm{L}$ tones. [sú/nú] are realized as $\mathrm{H}$ in the presence of $\mathrm{H}$. [súu/nú] induce downstepping of a following $\mathrm{H}$ if the argument it focuses is in the initial position. [sú/núl induce downstepping of a preceding $\mathrm{H}$ if it follows an argument specified as H. However, [súu/nú] do not lead to peak prominence if it is an L monosyllable like ày 'I'. On the other hand, [sú/núr] can emerge as a peak if the $\mathrm{L}$ tone is on a disyllable like dìi-khuo-nú 'water-Acc-MF'. No culminative or demarcative prominence could be found on the focused element. Rather, the MF marker which receives salience as it is assigned the highest tone. In these situations, phonological rephrasing can also be indicative of focus (Hyman 1999, Ladd 2008, Jun 1996, Hayes and Lahiri 1991). At the morpho-syntactic level, the mere addition of the focus marking morpheme does not result in the association of the focus marking $\mathrm{H}$ tone on the right edge of the focused argument. This association is found to be crucially sensitive to the phonological properties of the focused argument. Only a minimally disyllabic argument allows the focus marking $\mathrm{H}$ tone to get associated to the MF marker [sú/nú]. Such a relationship signifies that sentential phonology of a focused utterance in Boro relies heavily on the prosodic organization of the focused argument and morpho-syntactic processes cannot make the focused argument most salient at the phonological representation of the sentence.

Focus is a grammatical category that refers to new or highlighted information conveyed by a word or a phrase in the context of other background information in a sentence. The results of our experiments showed that Boro parted ways from some of the crosslinguistic tendencies (especially those of European languages) in its realization of $\mathrm{fo}$ in focused sentences. The reflexes of focus in Boro were marked not only morphologically but also prosodically. The strategies employed by Boro to mark focus prosodically are similar in some respects to those exploited by other languages but also differ in some other respects. Increased $\mathrm{f} 0$ of the focused element characterizes the highlighting of the focused element in a number of languages, which are English (Beckman and Pierrehumbert 1986), Korean (Jun 1993), Hausa (Inkelas and Leben 1990). The dominant cross-linguistic pattern entailing localized raising of f0 under focus was not found in Boro. In Boro, the most reliable cue for marking focus is not localized on thefocused element, rather, it is found to be on the MF marker in the case of in-situ morphological focus. Indeed, as a result of the realization of focus, the morphological marker only serves to lend prominence to the entire prosodic word, even though it is not expressed on the focused part of the word. This implies that Boro belongs to the type of language which need not necessarily highlight the focused element. This is relevant as Boro makes ample use of morphological markers to indicate focus unlike many other languages which have been studied extensively before for their prosodic properties of focus. Boro deviates from locally highlighting the focused element with increased f0 in both the MF marker and in-situ focus - in the presence of morphological focus it is the focus marker that emerges as the most prominent element and also in in-situ focus there was no clearly prominent part in the utterance. In in-situ focus, the cues for focus are not robust in the focused element itself, rather it appears phonetically in the post focus domain. This way of signaling 
focus is 'post focus compression' (PFC) as it has been recently noticed that focus is realized in many languages not only by increasing f0, duration, intensity and spectral energy on the focused component itself, but also by compressing the pitch range and intensity of the post-focus components (Chen et al. 2009, Cooper et al. 1985, Pell 2001; Xu 1999, 2005, Xu \& Xu 2005, Xu 2011). There is also evidence that such PFC is a highly effective perceptual cue for focus (Xu et al. 2004). Focus in Boro can be expressed by means of different linguistic strategies. It can be expressed in-situ, ex-situ and with the aid of MF markers [sul] or [nu]. In other words, the MF markers are found to be optional in expressing pragmatic prominence. The MF markers can occur interchangeably and can express pragmatic prominence on the arguments as well as on the verb. In other words they can put the subject, object or the verb on focus.

\section{The Experiment}

In a production study we examined the prosodic expression of focus in Boro, and in particular compared the tonal effects in two types of patterns -in the first pattern there was in-situ focus and in the second pattern the target words with in-situ focus appeared with MF markers. Four speakers of Boro were asked to produce scripted sentences of the target words in a carrier frame. This production experiment did not incorporate any fillers as sentences with various tonal patterns were used. Moreover the questionanswer pairs of various types were placed before the participants in a randomized pattern. Recordings were conducted at Bashbari and Kazigaon villages in the Parbatjhora sub-division in the district of Kokrajhar of the Autonomous Bodoland region in Assam (India)and the subjects were asked to read the sentences aloud. An Edirol Roland R-09HR with its inbuilt microphone was used for the recordings. The recordings were digitized at a sampling frequency of $44.1 \mathrm{~Hz}$ and 32 bit resolution. For in-situ focus, subjects were required to respond to questions in such a way that the first answer displayed broad focus, the second answer marked in-situ focus on subject, and the third answer would put in-situ focus prominence on the object NP or else the Adverbial in the VP. The same question-answer pattern was repeated to elicit answers with the MF markers [sú/núu] attached to the target subject NP, and the object NP and the Adverbial to see the effect of MF markers which also indicate in-situ focus in Boro (Brahma 2012).The two focus markers [súu] and [núl were tested for their influence on the tones of preceding and succeeding syllables in a sentence. Since Boro is a head final language, the subject (agent) canonically precedes the verb. The complements and adverbials also precede the head verb in the Verb Phrase.

2.1 Materials We constructed sentences to represent the following types in a SOV word order pattern $\left(2^{3}=\right.$ 8): We used the convention of parentheses ${ }^{3}$ to indicate that the tone is specified on the whole word irrespective of the number of syllables.

(2) Underlying tonal sequences and corresponding stimulus sequences

$$
(\mathrm{H})(\mathrm{H})(\mathrm{H})
$$

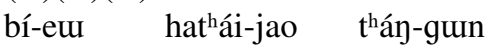

He-NOM market-LOC go-FUT

He will go to market.

bí-sur hathái-jao tháy-gun

He-Plural market-LOC go-FUT

They will go to market.

núin bé-k ${ }^{\mathrm{h}}$ uo sú-guin

you this-ACC wash-FUT

You will wash this.

(2ii) $\quad(\mathrm{L})(\mathrm{L})(\mathrm{L})$

ày dùi- $\mathrm{k}^{\mathrm{h}}$ uo bài-gun

I water-ACC buy-FUT

I will buy water.

(2iii) $\quad(\mathrm{H})(\mathrm{L})(\mathrm{H})$

\footnotetext{
${ }^{3}$ Accordingly, $(\mathrm{L})(\mathrm{H})(\mathrm{L})$ is categorically different from $\mathrm{LH}$, where the former $(\mathrm{L})$ within parentheses indicate a tone specified for the entire word, and the latter L indicates a tone on a TBU only.
} 
bí-surr dùi-k ${ }^{\mathrm{h}}$ uo lún-bay

he-Plural water-ACC drink-PRF

They have drunk water.

got òu-á dùi-k ${ }^{\mathrm{h}}$ uo lún-bay

child-NOM water-ACC drink-PRF

The child has drunk water

(2iv) $\quad(\mathrm{H})(\mathrm{H})(\mathrm{L})$

nún-ni bibár-á gup ${ }^{\mathrm{h}}$ ùr

you-POSS flower-NOM white

Your flower is white.

got òu-á bibár bài-gun

child-NOM flower buy-FUT

The child will buy flower.

$(2 \mathrm{v}) \quad(\mathrm{L})(\mathrm{L})(\mathrm{H})$

àn dùi-k ${ }^{\mathrm{h}}$ uo lún-bay

I water-ACC drink-PRF

I have drunk water.

àn dùi lún-o

I water drink-PRS

I drink water.

(2vi) $\quad(\mathrm{L})(\mathrm{H})(\mathrm{L})$

ày bibár bài-gun

I flower buy-FUT

I will buy flower.

(2vii) $\quad(\mathrm{H})(\mathrm{L})(\mathrm{L})$

got òu-á dùi-k ${ }^{\mathrm{h}} u o$ bài-gun

child-NOM water-ACC buy-FUT

The child will buy water.

bí-sur dùi-k ${ }^{\mathrm{h}} u$ o bài-gun

He-Plural water-ACC buy-FUT

They will buy water.

(2viii) $\quad(\mathrm{L})(\mathrm{H})(\mathrm{H})$

àn bé-k $k^{\mathrm{h}}$ uro sú-gun

I this-ACC wash-FUT

I will wash this.

2.2 Methodology Four native male speakers of Boro were chosen for the production study. Two of the participants were from Bashbari village and the other two speakers were residents of Kazigaon village in Parbatjhora sub-division of Kokrajhar district. The speakers were between 22 and 28 years of age. All the speakers were college graduates and they had elementary knowledge of Assamese. None of the speakers had any previous record of hearing impairment. Each of the speakers was compensated for their participation in the production experiment and an honorarium of INR two hundred were given to them.

\section{Result: Intonation and Focus in Boro}

Many languages make substantial use of prosody to mark the information structural categories of topic, focus etc. As outlined in the previous sections, we conducted an experiment to understand the kind of prosodic means employed for implementing focus in Boro. In the following sections we discuss the results of in-situ focus in greater detail. 
3.1 In-situ focus: $f 0$ and duration The results of the experiment on in-situ focus did not show any clear difference between broad focus and narrow focus when the focused argument was analysed. We conducted a two tailed statistical t-test to compare the mean $\mathrm{f} 0$ of the words bearing broad focus and narrow focus (both on subject and object). The mean f0 of the vowel in broad focus was compared with the vowel in the subject in narrow focus. The same comparison was also carried out for the vowels receiving narrow focus in the object position. The results do not show any significant difference in the broad focus f0 values vis-avis those receiving narrow focus. Thus Boro does not follow the pattern of $\mathrm{f} 0$ modification as a result of focus marking found in studies like Chen et al. (2009).

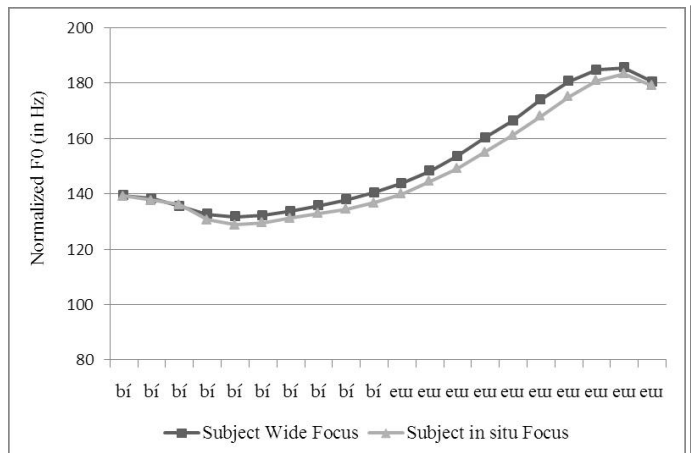

Figure 1(a)

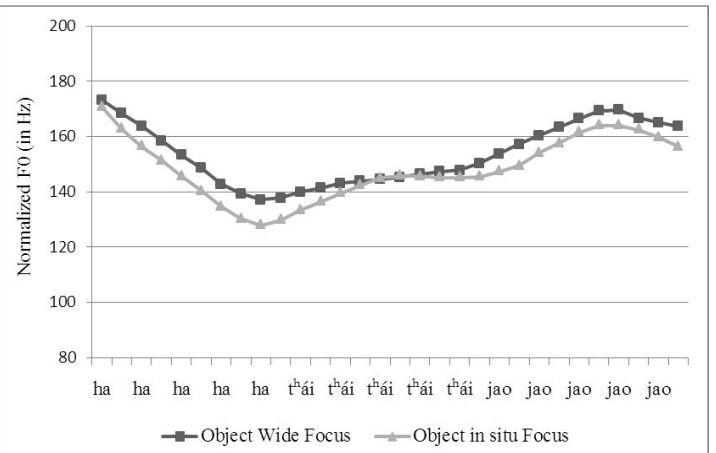

Figure 1(b)

Figures 1 (a) and 1 (b) present time-normalised course of mean f0 aggregated for all tokens across the speakers. 1 (a) compares the subject in broad focus and in-situ focus conditions (For 20 tokens, the Mean f0 of the subject with broad focus is $169.50 \mathrm{~Hz}$, Standard Deviation $(\mathrm{SD})=24.38$ and with in-situ focus it is $167.98 \mathrm{~Hz}, \mathrm{SD}=28.10$, with the $t$ stat value $=0.18$ ). 1 (b) compares the adverbial in the same conditions. For 20 tokens the Mean f0 of the adverbial expressing broad focus is $145.78 \mathrm{~Hz}, \mathrm{SD}=18.51$ and it is $143.96 \mathrm{~Hz}, \mathrm{SD}=18.24$ when the adverbial expresses in-situ focus, the $t$ stat value $=0.31$. These pitch tracks show that the contours for each type do not vary with respect to wide focus vis-a-vis narrow focus. The lighter line marks narrow focus and the darker line stands for broad focus.

3.2 Duration in In-situ focus A two tailed statistical t-test was conducted to measure the difference in average duration of the TBUs with broad focus versus narrow focus (both on subject and object) for all the sentence patterns. The average duration of the subject TBUs with broad focus was compared with the same with narrow focus for all the sentence patterns. The same comparison was made for the object TBUs. Our findings indicate that there is no significant difference in the duration of the vowels in broad focus and narrow focus conditions. A two tailed t-test confirms that there is no significant difference in the average duration between the vowels [a] in the syllable [àn] 'I' when compared with the one in broad focus condition (mean duration $=123.16 \mathrm{~ms}[\mathrm{n}=20]$ ) and in-situ focus on the subject (mean duration= $115.57 \mathrm{~ms}$ $[\mathrm{n}=20])(\mathrm{p}>.05[0.28], \mathrm{df}=38)$ in the sentence ày dùi lún-o 'I drink water'.

3.3 Discussion: Post-Focus compression Since we failed to find any correlate of focus in the focused element, we investigated the post focus components of the sentence. The results have shown that Boro indeed deploys PFC. The figures in 2(a) and 2(b) establish beyond doubt that in most instances across sentence types PFC plays a role when there is in-situ focus. The broad focus condition instantiates higher pitch range than the condition with in-situ focus where the post focus region was concerned. However, in the $(\mathrm{H})(\mathrm{L})(\mathrm{L})$ type in subject focus and $(\mathrm{L})(\mathrm{H})(\mathrm{H})$ type in object focus the observed differences from other types did not hold. 


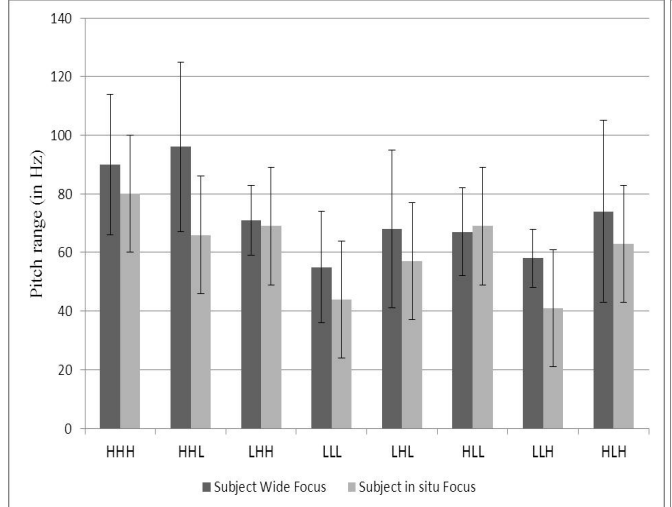

Figure 2(a)

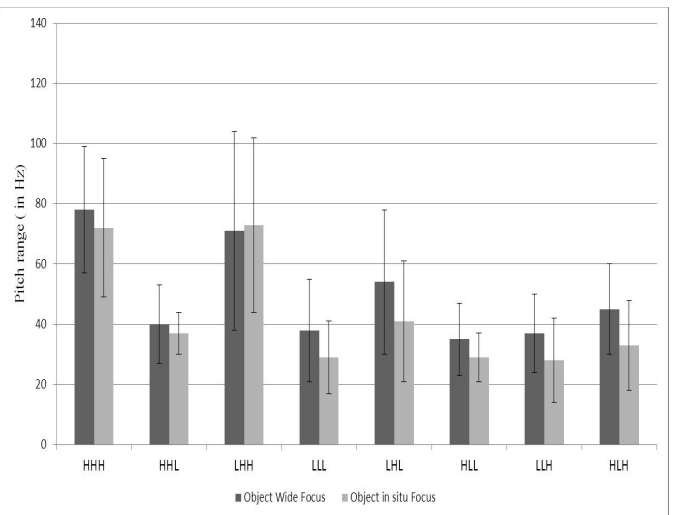

Figure 2 (b)

Figure 2 shows the comparison of PFC (pitch-range) for post focus component of the sentences (a) with and without focus on subject, and (b) with and without focus on object. The vertical axis shows the pitch range values in Hertz. The light gray scale shows the broad focus condition and the dark gray scale shows the post focus condition.

A comparison of average pitch range of constituents following arguments with and without in-situ focus in the sentence àn dùi-k $\mathrm{k}^{\mathrm{h}} \mathrm{u}$ o bài-gun 'I will buy water' $(\mathrm{n}=20)$ show that for most of the tokens there is post focus pitch range compression when ày ' $\mathrm{I}$ ' is invested with in-situ focus. A two tailed t-test showed that the average pitch-range of the Verb Phrase following the subject without focus (mean pitch range $=54.72 \mathrm{~Hz}, \mathrm{SD}=19.88)$ is significantly higher $(\mathrm{p}=0.001)$ than when the VP follows the focused ày 'I' (mean pitch range $=43.64 \mathrm{~Hz}, \mathrm{SD}=22.8$ ). A similar phenomenon of PFC is noticed when the object receives in-situ focus. The mean pitch range of bài-gun 'will buy' in the sentence ày dùi- $\mathrm{k}^{\mathrm{h}} u$ uo bài-gun 'I will buy water' $(38.77 \mathrm{~Hz} \mathrm{SD}=17.12, \mathrm{n}=20)$ when it follows the object dùi- $\mathrm{k}^{\mathrm{h}} \mathrm{uo}$ 'water' without in-situ focus is found to be more compared to its pitch range values when there is in-situ focus on dùi- $\mathrm{k}^{\mathrm{h}} \mathrm{uo}$ 'water' (mean pitch range $=29.14 \mathrm{~Hz}, \mathrm{SD}=12.13, \mathrm{p}=0.001$ ). Table 1 and 2 present in detail the post focus pitch range differences of in-situ focus on subject when compared to broad focus.

Table 1: Comparison of PFC of average pitch range (in Hertz) for post focus component of the sentence with and without in-situ focus on subject, $\mathrm{n}=20, \mathrm{df}=38$.

\begin{tabular}{|c|c|c|c|c|c|}
\hline Sentence types & $\begin{array}{c}\text { Mean pitch range Subject } \\
\text { in situ Focus [SD] }\end{array}$ & $t$ & $\begin{array}{c}\text { Mean pitch range Subject } \\
\text { wide focus [SD] }\end{array}$ & $t$ & Sig (2-tailed) \\
\hline HHH & $80.62[28.59]$ & 6.06 & $90.24[24.61]$ & 8.39 & 0.003 \\
\hline HHL & $65.84[18.41]$ & 16.39 & $95.94[29.83]$ & 7.35 & 0.003 \\
\hline LHH & $69.41[14.62]$ & 21.23 & $71.49[12.40]$ & 25.78 & 0.01 \\
\hline LLL & $43.64[22.8]$ & 8.56 & $54.72[19.88]$ & 12.31 & 0.001 \\
\hline LHL & $57.75[25.97]$ & 12.06 & $68.9[27.7]$ & 17.05 & 0.01 \\
\hline HLL & $68.68[20.97]$ & 8.88 & $67.09[15.82]$ & 14.11 & 0.79 \\
\hline LLH & $41.4[20.18]$ & 9.17 & $57.84[10.7]$ & 5.4 & 0.01 \\
\hline HLH & $62.55[28]$ & 15.44 & $73.71[31.24]$ & 17 & 0.02 \\
\hline
\end{tabular}

Table 2: Comparison of PFC of average pitch range (in Hertz) for post focus component of the sentence with and without in-situ focus on object.

\begin{tabular}{|c|c|c|c|c|c|}
\hline Sentence types & $\begin{array}{c}\text { Mean pitch range Object } \\
\text { in situ Focus [SD] }\end{array}$ & $t$ & $\begin{array}{c}\text { Mean pitch range Object } \\
\text { wide Focus [SD] }\end{array}$ & $t$ & Sig (2-tailed) \\
\hline HHH & $72.42[23.46]$ & 11 & $78.30[21.97]$ & 13.32 & 0.06 \\
\hline HHL & $37.23[7.7]$ & 21.61 & $40.8[13.17]$ & 13.85 & 0.001 \\
\hline LHH & $73.4[29.30]$ & 11.2 & $71.63[33.13]$ & 9.67 & 0.008 \\
\hline LLL & $29.14[12.13]$ & 10.47 & $38.77[17.12]$ & 9.59 & 0.001 \\
\hline LHL & $41.94[20.1]$ & 11.95 & $54.77[24.05]$ & 15.07 & 0.001 \\
\hline HLL & $29.18[8.53]$ & 15.31 & $35.61[12.97]$ & 12.28 & 0.004 \\
\hline LLH & $28.47[14.79]$ & 8.61 & $37[13.84]$ & 11.92 & 0.001 \\
\hline HLH & $33.33[14.99]$ & 11.14 & $45.45[15.52]$ & 13.09 & 0.001 \\
\hline
\end{tabular}


An examination of the duration of the post-focus parts of the sentences showed that the duration decreased when in-situ focus precedes these constituents. For example, in the sentence bí-eu hat ${ }^{\text {hái-jao }}$ thán-gun 'he will go to market' the duration of hathái-jao thán-gun 'will go to market' following bí-eu'he' without focus is found to be longer than when hat ái-jao thán-gun 'will go to market' is preceded by a focused bí-eu 'he'. A two tailed t-test showed that the average duration of the constituents following bí-eu 'he' without focus (mean duration=792.59 ms, $\mathrm{SD}=115.51)$ is significantly longer $(\mathrm{p}=0.001)$ than their average duration when they follow bí-eu 'he' with in-situ focus (mean duration= $763.27 \mathrm{~ms}, \mathrm{SD}=147.70$ ).

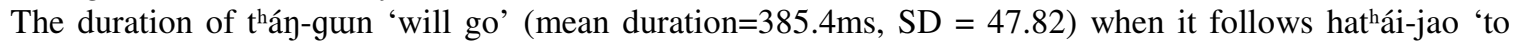
market' without focus is found to be more compared to its occurrence following focused hat ${ }^{\text {hai }}$-jao 'to market' (mean duration $=362.72 \mathrm{~ms}, \mathrm{SD}=58.79, \mathrm{p}=0.001$ ). Table 3 and 4 present in detail the post focus durational differences of in-situ focus on subject when compared to broad focus.

Table 3: Comparison of PFC of average duration (in ms) for post focus component of the sentence with and without in-situ focus on subject.

\begin{tabular}{|c|c|c|c|c|c|}
\hline $\begin{array}{c}\text { Sentence } \\
\text { types }\end{array}$ & $\begin{array}{c}\text { Mean duration Subject } \\
\text { in situ Focus [SD] }\end{array}$ & $t$ & $\begin{array}{c}\text { Mean duration Subject } \\
\text { wide Focus [SD] }\end{array}$ & $t$ & Sig (2-tailed) \\
\hline HHH & $763.27[147.70]$ & 23.11 & $792.59[115.51]$ & 30.69 & 0.001 \\
\hline HHL & $800.14[100.44]$ & 36.5 & $823[136]$ & 26.94 & 0.001 \\
\hline LHH & $788.7[147.88]$ & 23.85 & $803.15[127.90]$ & 28.08 & 0.01 \\
\hline LLL & $665.82[109.32]$ & 27.24 & $695.46[110.88]$ & 28.05 & 0.001 \\
\hline LHL & $635.6[58.15]$ & 33 & $666.55[51.41]$ & 37.88 & 0.001 \\
\hline HLL & $709.48[101.24]$ & 24.35 & $709.31[78.61]$ & 28.77 & 0.99 \\
\hline LLH & $676.62[105]$ & 28.82 & $703.1[134.25]$ & 23.42 & 0.001 \\
\hline HLH & $655.62[83.22]$ & 31.05 & $662.69[85.85]$ & 33.15 & 0.78 \\
\hline
\end{tabular}

Table 4: Comparison of PFC of average duration (in ms) for post focus component of the sentence with and without in-situ focus on object.

\begin{tabular}{|c|c|c|c|c|c|}
\hline $\begin{array}{c}\text { Sentence } \\
\text { types }\end{array}$ & $\begin{array}{c}\text { Mean duration Object in } \\
\text { situ Focus [SD] }\end{array}$ & $t$ & $\begin{array}{c}\text { Mean duration Object } \\
\text { wide Focus [SD] }\end{array}$ & $t$ & Sig (2-tailed) \\
\hline HHH & $362.72[58.79]$ & 27.59 & $385.4[47.82]$ & 36.04 & 0.001 \\
\hline HHL & $409.16[78.87]$ & 23.20 & $410.08[62.76]$ & 29.22 & 0.01 \\
\hline LHH & $443.78[93.32]$ & 21.26 & $459.11[78.84]$ & 26.04 & 0.01 \\
\hline LLL & $328.29[52.48]$ & 27.98 & $364.38[64.87]$ & 25.12 & 0.001 \\
\hline LHL & $330.5[59.11]$ & 22.55 & $325.5[54.27]$ & 28.78 & 0.78 \\
\hline HLL & $350.34[51.79]$ & 31 & $353.22[38.11]$ & 27 & 0.83 \\
\hline LLH & $357.81[70.6]$ & 22.67 & $377.55[73.47]$ & 22.98 & 0.01 \\
\hline HLH & $377.3[43.06]$ & 19.79 & $374.8[50.28]$ & 20.22 & 0.87 \\
\hline
\end{tabular}

From the results presented above, except for a $(\mathrm{H})(\mathrm{L})(\mathrm{L})$, PFC has emerged as a strong contender for phonetic correlate of in-situ focus in Boro. While the $(\mathrm{H})(\mathrm{L})(\mathrm{H})$ pattern shows that pitch range is significantly compressed (but not duration), $(\mathrm{H})(\mathrm{L})(\mathrm{L})$ is the only pattern which does not instantiate any compression either in terms of duration or pitch range. This leads us to believe that in-situ focus may be phonetically expressed as either pitch range or duration compression or both in most of the cases. However, if there is an $\mathrm{H}$ tone preceding the $\mathrm{L}$ tone $(\mathrm{s})($ as in $(\mathrm{H})(\mathrm{L})(\mathrm{L}))$ pitch range compression does not appear at all.

\section{Identification Test}

The experiment consisted of an identification task in which the participants had to categorize the auditory stimuli as conveying either in-situ focus on the subject or in-situ focus on the object/adverbial. Initially the experiment consisted of sentences with broad focus, in situ focus on subject and in situ focus on object/adverbial. Then two series of randomized sentences, with the first series consisting of broad focus and in situ focus on subject and the second series with broad focus and in situ focus on the object/adverbial 
were presented to the participants. The result showed that the participants could not distinguish between the sentences in each of these two series. In view of this, the broad focus sentences were left out of this identification task and the experiment included sentences with in situ focus on subject and in situ focus on object/adverbial. Natural speech data for the production study mentioned above were used for this experiment. The sentences were in the form of answers to questions where the narrow focus is on the subject or the object/adverbial. The objective of this experiment was to evaluate the ability of the participants to perceive the difference between sentences based on in situ focus on subject or object/adverbial, given the fact that in situ focus in Boro is expressed through PFC and not bringing about any change in the F0 or durational values of the arguments.

A set of 8 native speakers of Boro participated in this experiment. All the participants were male between 22 and 35 years of age. The participants were asked to assign randomly presented stimuli from the series of sentences to either of the two categories: expressing subject focus or object/adverbial focus. The sound files of the sentences with the following tonal pattern, used in the above production experiment, were randomly played to the participants for this task: HHH, HHL, HLL, LHH, LHL, LLH, HLH and LLL.

The experiment was first explained to the participants and they were also instructed to pay attention to the tunes of the stimuli which consisted of the same words but expressed prosodic prominence on two different words: either on the subject or on the object/adverbial. Each pair of answers was first played to the participants as part of a short training session. They were also instructed that the experiment required them to put a right mark on a table next to the question which they feel should be related to the answer they have heard in each sound filed played to them. The table consisted of three columns: the first one displayed questions anticipating subject prominence in the answer, the second column contained questions requiring object/adverbial prominence in the answer, and the participants were asked to put a right mark in the third column if they are not able to decide whether a given sentence expresses subject or object/adverbial prominence. Each sentence with each focus condition was repeated five times at randomly selected intervals during the experiment. Following this a total number of 640 ( 8 sentences $x$ two focus conditions $x$ 5 repetitions $x 8$ participants) responses were obtained at the end of the task. The stimuli were played to the participants with the help of a computer in a sound proof recording booth at the Phonetics and Phonology Lab of IIT Guwahati.

Table 5: Results of the identification task.

\begin{tabular}{|c|c|c|c|c|}
\hline Tone Pattern & Focus type & Stimuli & Positive Response & Negative Response \\
\hline \multirow[t]{2}{*}{$\mathrm{HHH}$} & Subject & 40 & 34 & 6 \\
\hline & Adverbial & 40 & 32 & 8 \\
\hline \multirow[t]{2}{*}{ HHL } & Subject & 40 & 33 & 7 \\
\hline & Object & 40 & 31 & 9 \\
\hline \multirow[t]{2}{*}{ HLL } & Subject & 40 & 32 & 8 \\
\hline & Object & 40 & 34 & 6 \\
\hline \multirow[t]{2}{*}{$\mathrm{LHH}$} & Subject & 40 & 30 & 10 \\
\hline & Object & 40 & 33 & 7 \\
\hline \multirow[t]{2}{*}{ LHL } & Subject & 40 & 34 & 6 \\
\hline & Object & 40 & 33 & 7 \\
\hline \multirow[t]{2}{*}{ LLH } & Subject & 40 & 32 & 8 \\
\hline & Object & 40 & 34 & 6 \\
\hline \multirow[t]{2}{*}{ LLL } & Subject & 40 & 32 & 8 \\
\hline & Object & 40 & 33 & 7 \\
\hline \multirow[t]{2}{*}{$\mathrm{HLH}$} & Subject & 40 & 31 & 9 \\
\hline & Object & 40 & 30 & 10 \\
\hline
\end{tabular}

The results of the identification task presented above in Table 5 show that Boro speakers can distinguish between in situ focus on the subject as opposed to in situ focus on the object/adverbial. It can be seen that for all the types of sentence patterns the participants show a highest of $85 \%$ and a lowest $75 \%$ positive responses in distinguishing between these two types of focus. Since this result has been obtained for all the patterns, we can be certain that post focus compression is indeed at work in Boro, but apart from that there may be some other correlate which is not entirely apparent from our results. The results also suggest that in situ focus exists as a perceptually viable means of expressing focus in Boro. More perception tests may reveal whether MF markers are preferred over in situ focus marking in Boro. 
Table 6: Difference between Mean F0 of sentences between two consecutive H tones.

\begin{tabular}{|c|c|c|c|c|c|c|}
\hline Sentence & $\begin{array}{l}\text { Sentence } \\
\text { Type }\end{array}$ & \multicolumn{2}{|c|}{$\begin{array}{c}\text { Difference between (mean/average fo } \\
[\text { in } \mathrm{Hz}])[S D]\end{array}$} & $\begin{array}{c}\text { Number of } \\
\text { tokens }\end{array}$ & $t$ stat & $\begin{array}{c}\mathrm{p} \\
\text { value }\end{array}$ \\
\hline $\begin{array}{l}\text { bí-eu hathaí-jao-sú } \\
\text { tháy-gun. }\end{array}$ & $\mathrm{HHH}$ & $\begin{array}{c}\text { jao }](147.32) \\
{[16.44]} \\
\end{array}$ & $\begin{array}{c}\text { [stút }(175.38) \\
{[30.67]} \\
\end{array}$ & $20[\mathrm{df}=38]$ & -4.28 & 0.0001 \\
\hline $\begin{array}{l}\text { bí-em-súu hathaí-jáo } \\
\text { thán-gumn. }\end{array}$ & $\mathrm{HHH}$ & $\begin{array}{c}\text { [eúi] }(151.49) \\
{[16.44]}\end{array}$ & $\begin{array}{c}\text { [súi] }(183.98) \\
{[30.67]}\end{array}$ & $20[\mathrm{df}=38]$ & -4.27 & 0.0001 \\
\hline $\begin{array}{l}\text { bí-eu hat aí-jao-nú } \\
\text { thán-guin. }\end{array}$ & HHH & $\begin{array}{c}{[\mathrm{jao}](150.16)} \\
{[23.85]}\end{array}$ & $\begin{array}{c}\text { [núu }(172.94) \\
{[29.61]}\end{array}$ & $20[\mathrm{df}=38]$ & -2.82 & 0.008 \\
\hline $\begin{array}{l}\text { bí-eui-nú hat haí-jao } \\
\text { tháy-guin. }\end{array}$ & $\mathrm{HHH}$ & $\begin{array}{l}\text { [ex́i] }(147.95) \\
{[18.55]}\end{array}$ & $\begin{array}{c}\text { [núi }](178.10) \\
{[29.55]}\end{array}$ & $20[\mathrm{df}=38]$ & -4.28 & 0.0001 \\
\hline $\begin{array}{c}\text { bí-sur-sú há-thaí-jao } \\
\text { tháy-gun }^{\text {há }} \\
\end{array}$ & $\mathrm{HHH}$ & $\begin{array}{c}\text { [sur] }(157.76) \\
{[25.27]}\end{array}$ & $\begin{array}{c}\text { [súi] }(177.81) \\
{[28.78]}\end{array}$ & $20[\mathrm{df}=38]$ & -2.34 & 0.02 \\
\hline $\begin{array}{c}\text { bí-surrhathaí-jao-sú } \\
\text { tháy-gun }^{\text {tha }}\end{array}$ & $\mathrm{HHH}$ & $\begin{array}{c}\text { [jao }(146.56) \\
{[20.86]}\end{array}$ & $\begin{array}{c}\text { [súi] }(172.59) \\
{[31.38]}\end{array}$ & $20[\mathrm{df}=38]$ & -3.09 & 0.003 \\
\hline $\begin{array}{c}\text { núuy-sú bé-k } k^{\text {h }} \text { uio sú- } \\
\text { guin }\end{array}$ & НHH & $\begin{array}{c}\text { [núm] }](126.61) \\
{[15.43]}\end{array}$ & $\begin{array}{c}\text { [súu }](129.16) \\
{[12.54]}\end{array}$ & $20[\mathrm{df}=38]$ & -0.62 & 0.54 \\
\hline $\begin{array}{l}\text { nún bé-k'utuo-sú } \\
\text { sú-guin }\end{array}$ & $\mathrm{HHH}$ & 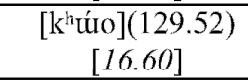 & $\begin{array}{c}\text { [súl] }(146.92) \\
{[14.51]}\end{array}$ & $20[\mathrm{df}=38]$ & -3.53 & 0.001 \\
\hline ày-sú dùi lúy-っ & LLH & $\begin{array}{c}\text { [àn] }(136.48) \\
{[16.75]}\end{array}$ & $\begin{array}{c}\text { [súu }](142.14) \\
{[18]}\end{array}$ & $20[\mathrm{df}=38]$ & -1.03 & 0.31 \\
\hline Ày dùi-scú lúy-o & LLH & $\begin{array}{c}\text { [dùi }](132.46) \\
{[17.78]}\end{array}$ & $\begin{array}{c}\text { [súi] }(135.23) \\
{[18.52]}\end{array}$ & $20[\mathrm{df}=38]$ & -0.48 & 0.63 \\
\hline $\begin{array}{l}\text { núm-ni bí-bar-a-núu } \\
\text { gù-p phur }\end{array}$ & HHL & $\begin{array}{c}\text { [á] }(141.04) \\
{[22.66]}\end{array}$ & $\begin{array}{c}\text { [núu }(138.05) \\
{[18.27]}\end{array}$ & $20[\mathrm{df}=38]$ & 0.49 & 0.62 \\
\hline $\begin{array}{c}\text { núuy-ni-núu bí-bar-a } \\
\text { gù-p } \text { ph }^{\text {h }} \text {. } \\
\end{array}$ & HHL & $\begin{array}{c}\text { [ní] }(140.35) \\
{[19.15]}\end{array}$ & $\begin{array}{c}\text { [núu }](158.29) \\
{[13.12]}\end{array}$ & $20[\mathrm{df}=38]$ & -3.71 & 0.0005 \\
\hline $\begin{array}{l}\text { bí-sur-súi dùi- } k^{\mathrm{h}} \text { mo } \\
\text { bai-gumn }\end{array}$ & HLL & $\begin{array}{c}{[\text { sur }](154)} \\
{[21.81]}\end{array}$ & $\begin{array}{c}{[\text { súl }](169.41)} \\
{[26.70]}\end{array}$ & $20[\mathrm{df}=38]$ & -2.14 & 0.04 \\
\hline $\begin{array}{l}\text { bí-surr dùii-khtuo-sú } \\
\text { bai-guin }\end{array}$ & HLL & $\begin{array}{c}{\left[\mathbf{k}^{\mathrm{h}} \mathbf{u} \mathbf{o}\right](131.32)} \\
{[21.47]} \\
\end{array}$ & $\begin{array}{c}\text { [súu }](152.79) \\
{[23.65]} \\
\end{array}$ & $20[\mathrm{df}=38]$ & -3.22 & 0.002 \\
\hline ày-súu bé-k"huosú-gun & LHH & $\begin{array}{c}\text { [ày] }(125.34) \\
{[22.28]}\end{array}$ & $\begin{array}{c}\text { [súi] }(126.19) \\
{[13.01]}\end{array}$ & $20[\mathrm{df}=38]$ & -0.14 & 0.88 \\
\hline 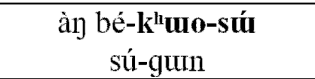 & LHH & $\begin{array}{c}{\left[\mathbf{k}^{\mathrm{h}} \mathbf{w o}\right](122.9)} \\
{[15.13]}\end{array}$ & $\begin{array}{c}\text { [stíl] }(143.71) \\
{[25.31]}\end{array}$ & $20[\mathrm{df}=38]$ & -3.16 & 0.003 \\
\hline 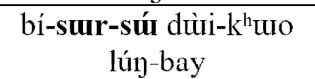 & $\mathrm{HLH}$ & $\begin{array}{c}\text { [surr] }(154.27) \\
{[23.98]}\end{array}$ & $\begin{array}{c}\text { [súi] }(166.49) \\
{[26.73]}\end{array}$ & $20[\mathrm{df}=38]$ & -1.52 & 0.14 \\
\hline $\begin{array}{l}\text { bí-surr dùi-k }{ }^{\mathrm{h} u \text { uo-súu }} \\
\text { lún-bay }\end{array}$ & $\mathrm{HLH}$ & $\begin{array}{c}{\left[\mathbf{k}^{\mathrm{h}} \mathbf{u} \mathbf{o} \mathbf{0}(130.24)\right.} \\
{[22.35]} \\
\end{array}$ & $\begin{array}{c}\text { [súu] }(159.23) \\
{[25.4]} \\
\end{array}$ & $20[\mathrm{df}=38]$ & -3.91 & 0.0003 \\
\hline ày-súu bí-bar bài- guin & LHL & $\begin{array}{c}\text { [àn] (131.14) } \\
{[16.38]}\end{array}$ & $\begin{array}{c}\text { [súi] }(134.68) \\
{[22.20]}\end{array}$ & $20[\mathrm{df}=38]$ & -0.57 & 0.570 \\
\hline àn bi-bár-sú bài- yun & LHL & $\begin{array}{c}\text { [bár] (136.86) } \\
{[21.25]}\end{array}$ & $\begin{array}{c}\text { [súi] }(154.57) \\
{[33.57]}\end{array}$ & $20[\mathrm{df}=38]$ & -1.99 & 0.05 \\
\hline $\begin{array}{c}\text { got òul-a-súl } \\
\text { dùi-k-kho lún-bay }\end{array}$ & $\mathrm{HLH}$ & $\begin{array}{c}{[\mathrm{a}](137.41)} \\
{[15.43]}\end{array}$ & $\begin{array}{c}\text { [súi] }(162.11) \\
{[26.29]}\end{array}$ & $20[\mathrm{df}=38]$ & -3.71 & 0.0006 \\
\hline 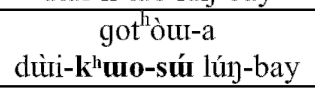 & HLH & $\begin{array}{c}{\left[\mathrm{k}^{\mathrm{h}} \mathrm{ulo}\right](129.81)} \\
{[21.32]} \\
\end{array}$ & $\begin{array}{c}\text { [súu }(150.60) \\
{[23.53]} \\
\end{array}$ & $20[\mathrm{df}=38]$ & -3.07 & 0.003 \\
\hline $\begin{array}{l}\text { ày-sú dùi-k }{ }^{\mathrm{h}} \text { uo } \\
\text { bài- guun }\end{array}$ & LLL & $\begin{array}{c}\text { [àn] (135.92) } \\
{[19.9]}\end{array}$ & $\begin{array}{c}\text { [súi] (141.40) } \\
{[25]}\end{array}$ & $20[\mathrm{df}=38]$ & -0.77 & 0.44 \\
\hline $\begin{array}{c}\text { ày dùi-k-k }{ }^{\mathbf{h}} \mathbf{u o} \text {-súu } \\
\text { bài- guun }\end{array}$ & LLL & $\begin{array}{c}{\left[\mathrm{k}^{\mathrm{h}} \mathrm{uio}\right](128.62)} \\
{[21.71]}\end{array}$ & $\begin{array}{c}\text { [súu] }(162.77) \\
{[30.15]}\end{array}$ & $20[\mathrm{df}=38]$ & -4.11 & 0.0002 \\
\hline
\end{tabular}

\section{Morphological Focus (MF) Marker}

This paper also addresses the question whether languages with morphological marking of focus also utilize prosodic cues to signal focus. In Wolof, a language which has morphological focus markers like Boro, does not use intonation to signal focus (Rialland and Robert 2001). However, our results show that 
the morphological focus markers in Boro indeed bring about significant difference in the f0 trend. In a $(\mathrm{H})(\mathrm{H})(\mathrm{H})$ sentence, the MF markers [sú/núu] bear the highest peak if the subject is underlyingly $\mathrm{H}$. The f0 maximum in [sú/nú] is much higher than the f0 maximum in -eur 'Nom' (for example, mean F0 for [sú] = $183.98 \mathrm{~Hz}$, and $[\mathrm{eu}]=151.49 \mathrm{~Hz}, \mathrm{n}=20, \mathrm{p}<0.0001$, in the sentence bí-eu-sú hathái-jao thán-gun 'He will go to market') showing that the MF marker is the most prominent. The MF markers [súu/núu bear the highest peak if the subject is underlyingly $\mathrm{H}$ tone. The f0 maximum in [sú/nú] is much higher than the f0 maximum in eu 'Nom' showing that the MF marker is the most prominent. Table 6 shows the statistical findings in detail. In this pattern the highest peak is borne by [súi] when it follows the subject. While the broad focus sentence is illustrative of some amount of downstepping if the following TBU is high, significant anticipatory downstepping is noticed only if the MF marker follows the object.

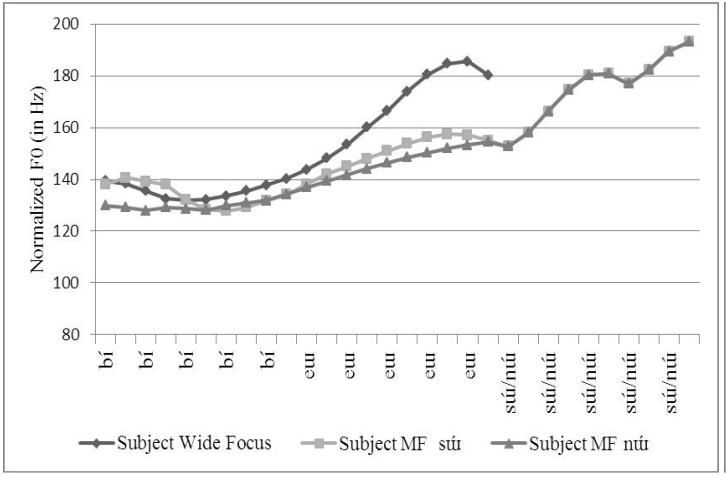

Figure 3 (a)

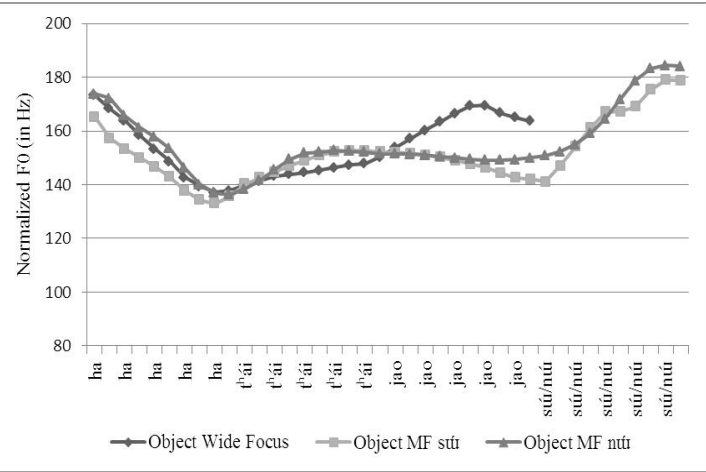

Figure 3 (b)

Figure 3: Time-normalized course of mean f0 aggregated for male speakers $(n=20,4$ speakers $x$ 5iterations each). Figure 3(a) represents the contours of the subject bíeu 'he' with broad focus and morphological focus [sú/núu] conditions in the sentence bí-eu[sú/nú] hat ái-jao tháy-gun 'he (MF) will go to market'. Whereas, Figure 3(b) represents the contours of the object hat ái-jao 'market' in broad focus and morphological focus [súu/nú] conditions in the same sentence (bí-eur hat ${ }^{\text {hái- }}$ jao[súi/núl] tháy-gun 'he will go to market (MF)). 10 measuring points per syllable are displayed.

In the $(\mathrm{H})(\mathrm{H})(\mathrm{H})$ sentence, in the broad focus condition, there are two peaks- one aligned to the mid part of the second syllable of the subject and the other aligned to the third syllable of the second word. The first fall is aligned to the vowel of the first syllable of the second word. If the same sentence appears with a MF marker, in a clear difference to in-situ focus, it is not the first content word which receives the peak, it is the MF marker which is realized as a peak. If MF is on the subject, it leads to the delayed rise which is a slightly raised plateau without any peak on hathái 'market'. If MF is on the second word downstepping is entirely different. The $\mathrm{H}$ tone appears lowered in the first word and there is anticipatory $\mathrm{H}$ tone lowering as shown in Figure 3 above.

In $(H)(L)(H)$ type of sentences in the presence of focus on the subject, the peak pitch is on [sú/núl] if focus is on the subject. The rest of the pitch track has a falling contour. If the focus marker is on the object the peak emerges on the L after dùi-k $\mathrm{k}^{\mathrm{h} u o}$ 'water-Acc'. The IP boundary tone for both is LL\%. Figure 4 shows how the peak aligns when the MF marker occurs with the subject or object in $(H)(L)(H)$ type of sentence.

This paper has shown that Boro marks focus not only morphologically but also through prosody. Focus related morphemes show that rather than the constituent they place in focus, it is the focus morpheme which emerges as phonetically more prominent.

5.1 Disyllabicity and Morphology-Phonology interface It is discussed in the above sections that the morphological focus marker is inherently specified with tone which overrides the $\mathrm{H}$ and $\mathrm{L}$ tones of the TBU, such that the $\mathrm{H}$ tone is much higher than its usual $\mathrm{H}$ and there is a peak even after the $\mathrm{L}$ tone. However, where words have an $\mathrm{L}$ specification and monosyllabic structure, as in the sentence type $(\mathrm{L})(\mathrm{L})(\mathrm{H})$ the MF marker does not emerge with the highest peak. In the presence of monosyllables, the MF marker does not show any peak which leads to significant raising. In the $(\mathrm{L})(\mathrm{H})(\mathrm{L})$ pattern as well, the sentence bearing subject focus showed that if the subject is an L monosyllable, then the MF marker does not emerge with the highest peak. 
It can be seen from Figure 5 that àn-nú 'I (MF)' surfaces without any peak and dùi-khuo-nú 'water (MF)' surface with a raised peak on the third syllable, which is the MF marker.

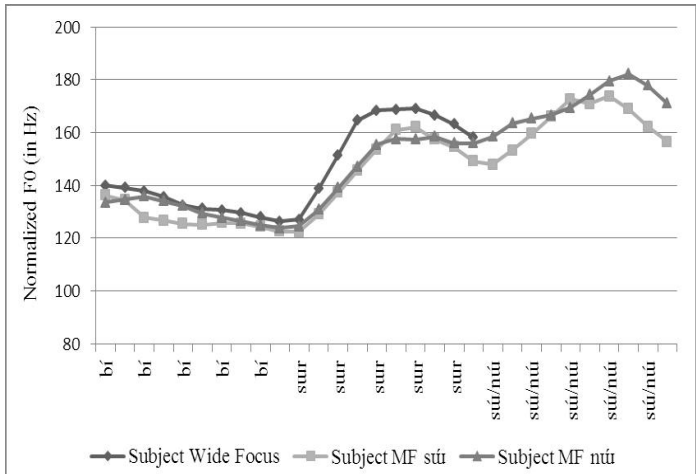

Figure 4 (a)

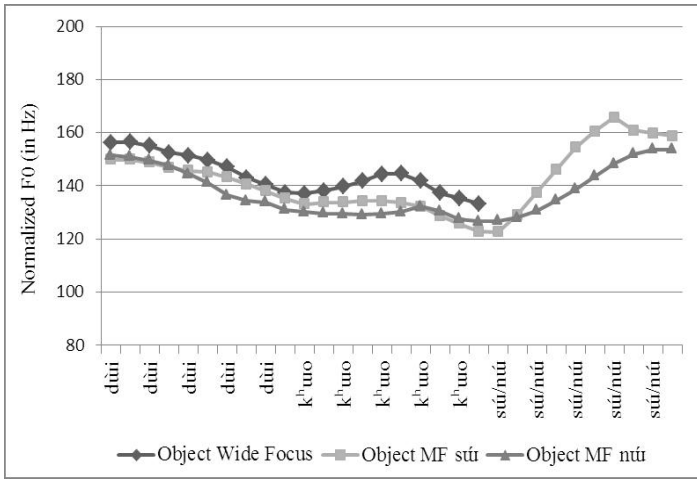

Figure 4 (b)

Figure 4: Time-normalized mean f0 aggregated for male speakers $(n=20,4$ speakers $x$ 5iterations each]). Figure 4 (a) represents the contours of the subject bí-surr 'they' with broad focus and morphological focus [sú/núu] conditions in the sentence bí-surr[sú/núu] dùi-khiuo lúy-bay 'they (MF) have drunk water'. Figure 4 (b) represents the contoursof the object dùi-k ${ }^{\mathrm{h}} u$ o 'water-Acc' with broad focus and morphological focus [sú/núu] conditions in the same sentence bí-sur dùik ${ }^{\mathrm{h}} u o[\mathrm{sú} / \mathrm{nú}]$ lún-bay 'they have drunk water' $(\mathrm{MF}) .10$ measuring points per syllable are displayed.
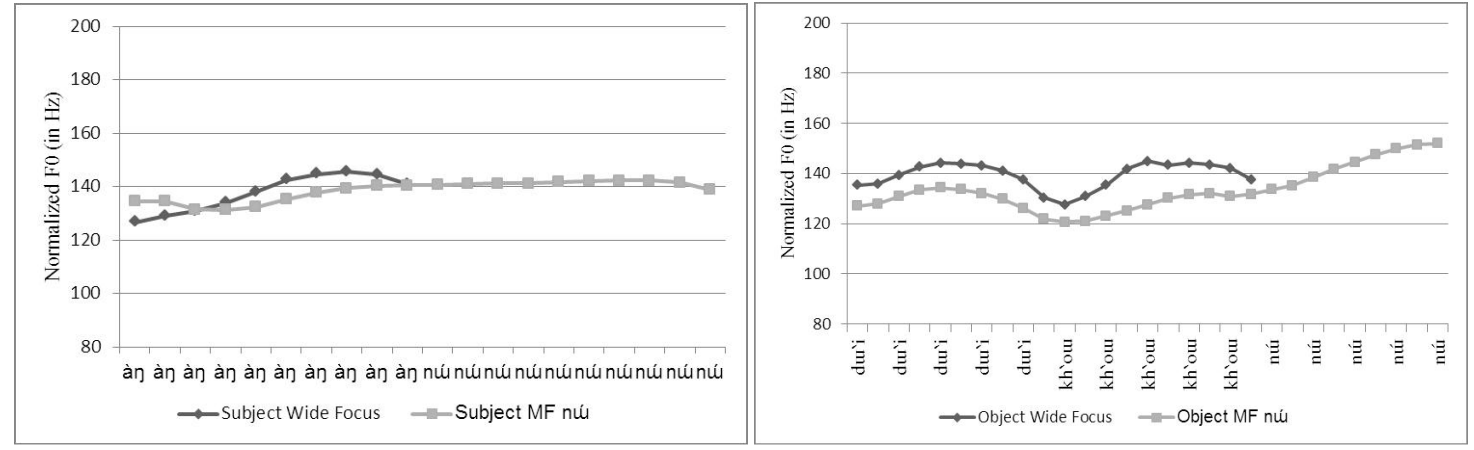

Figure 5 (a)

Figure 5 (b)

Figure 5: Time-normalized course of mean $\mathrm{f0}$ aggregated for male speakers $(\mathrm{n}=20$, 4 speakers $\mathrm{x}$ 5iterations each) of the sentence ày dùi-k ${ }^{\mathrm{h}}$ uo bài-gun 'I will buy water'with wide focus and morphological focus [núl] on subject [5 (a)] and object [5 (b)]. 10 measuring points per syllable are displayed.

Das and Mahanta (2016b) show that the minimum prosodic word domain in Boro is disyllabic and only one lexical tone is allowed to surface within this domain in a right-aligned manner. This is also corroborated by [sú/núl] which fail to appear as an $\mathrm{H}$ tone in the absence of a disyllable. Thus the difference in the contour height on the MF marker results from the fact that the argument in Figure 5 (a) is monosyllabic and the one in Figure 5 (b) is disyllabic.

\section{Conclusion}

The results presented above show that morphological focus markers are constrained prosodically in expressing focus in Boro. The phonetic changes confirm that at the phrasal level, Boro $\mathrm{H}$ tones are realized with a higher peak in the presence of the MF markers [súu] and [núu. These focus markers are specified with the pitch accent $\mathrm{H}^{*}$. This is seen to be the result in the presence of focus markers in both the first and second positions of the sentence. In this, we see that not only the focus marker does not condition the phonological behavior of the base stem, in fact it only gets affected by the prosodic properties of the base. While we have to understand prosody-focus and prosody-syntax relationships in Boro in greater detail, this 
instance provides us a glimpse of the way in which prosodic organization may constrain the phonological reflexes of morpho-syntactic elements.

\section{References}

Beckman, Mary E. and Janet B. Pierrehumbert. 1986. Intonational structure in Japanese and English. Phonology 3(01):255-309.

Bhattacharya, Pramod Chandra. 1977. A Descriptive Analysis of the Bodo Language. Department of Publication: Guwahati University.

Burling, Robbins.1959. Proto-Bodo. Language 35(3):433-453.

Chen, Szu-wei, Bei Wang, and Yi Xu. 2009. Closely related languages, different ways of realizing focus. In Proceedings of Interspeech 2009: 1007-1010.

Cooper, William E., Stephen J. Eady, and Pamela R. Muller. 1985. Acoustical aspects of contrastive stress in questionanswer contexts. The Journal of Acoustical Society of America 77:2142-2156.

Das, Kalyan and Shakuntala Mahanta. 2016a (forthcoming). Focus marking and pitch register modification in Boro. Speech Prosody 2016.

Das, Kalyan and ShakuntalaMahanta. 2016b (forthcoming). Tonal Alignment and Prosodic Word domain in Boro. The 5the International Symposium on Tonal Aspects of Languages. ISCA.

Das, Kalyan and ShakuntalaMahanta. (forthcoming). Alignment and Interaction between Lexical and Intonational Tones in Boro.

Gussenhoven, Carlos and Peter Van der Vliet. 1999. The phonology of tone and intonation in the Dutch dialect of Venlo. Journal of Linguistics 35(1):99-135.

Gussenhoven, Carlos. 2004. The Phonology of Tone and Intonation. Cambridge: Cambridge University Press.

Hayes, Bruce and Aditi Lahiri. 1991. Bengali intonational phonology. Natural Language \& Linguistic Theory 9(1):4796.

Hyman, Larry M. 1999.The interaction between focus and tone in Bantu. In Georges Rebuschi and Laurie Tuller, eds., The Grammar of Focus, pages 151-177. Amsterdam: John Benjamins.

Inkelas, Sharon and William Leben. 1990. Where phonology and phonetics intersect: the case of Hausa intonation. In John Kingston, Mary E. Beckman eds., Papers in Laboratory Phonology I: Between the Grammar and the Physics of Speech, pages 17-34. Cambridge University Press.

Joseph, Umbavu Varghese and Robbins Burling. 2006. The Comparative Phonology of the Bodo-Garo Languages. Mysore: Central Institute of Languages.

Jun, Sun-Ah. 1993. The Phonetics and Phonology of Korean Prosody. Ph.D.thesis, The Ohio State University

Jun, Suh-Ah. 1996. The Phonetics and Phonology of Korean Prosody: Intonational Phonology and Prosodic Structure.Taylor\& Francis.

Karlsson, Anastasia M., Jan-Olof Svantesson, and David House. 2012. Adaptation of focus to lexical tone and phrasing in Kammu. In Proceedings of the Third International Symposium on Tonal Aspects of Languages.http://www.tal2012.org/papers/O3-01.pdf

Kügler, Frank and Susanne Genzel.2012. On the prosodic expression of pragmatic prominence-The case of pitch register lowering in Akan. Language and Speech 55(3):331-359.

Ladd, Robert D. 2008. Intonational Phonology. Cambridge University Press.

Myers, Scott. 1996. Boundary tones and the phonetic implementation of tone in Chichewa. Studies in African Linguistics 25:29-60.

Pell, Mark D. 2001. Influence of emotion and focus on prosody in matched statements and questions. Journal of the Acoustical Society of America 109:1668-1680.

Rialland, Annie and Stéphane Robert. 2001. The intonational system of Wolof. Linguistics 39:893-939.

Sarmah, Priyankoo. 2004. Some Aspects of the Tonal Phonology of Bodo. M.Phil. dissertation, CIEFL, Hyderabad.

Truckenbrodt, Hubert. 1995. Phonological Phrases: Their Relation to Syntax, Focus, and Prominence. Ph.D. thesis, MIT.

$\mathrm{Xu}$, Yi. 1999. Effects of tone and focus on the formation and alignment of f0 contours. Journal of Phonetics, 27(1):55105.

$\mathrm{Xu}$, Yi. 2005. Speech melody as articulatorily implemented communicative functions. Speech Communication 46(3):220-251.

Xu, Yi, Ching X. Xu, and Xuejing Sun. 2004. On the temporal domain of focus. Speech Prosody 2004.

$\mathrm{Xu}$, Yi, and Ching X. Xu. 2005. Phonetic realization of focus in English declarative intonation. Journal of Phonetics 33(2):159-197.

Xu, Yi. 2011. Post-focus compression: Cross-linguistic distribution and historical origin. In Proceedings of the 17th International Congress of Phonetic Sciences, pages 152-155. Hong Kong.

Xu, Yi. 2013. ProsodyPro- A Tool for Large-scale Systematic Prosody Analysis. In Proceedings of Tools and Resources for the Analysis of Speech Prosody (TRASP 2013), Aix-en-Provence, France.7-10. 